\title{
Preoperative Vitamin D Level Predicts Operative Mortality After Cardiac Surgery
}

\author{
๑ Atike Tekeli Kunt1, ๑ Naim Boran Tümer², ๑ Kanat Özışık², ๑ Serdar Günaydın²
}

${ }^{1}$ Kırıkkale University Faculty of Medicine, Department of Cardiovascular Surgery, Kırıkkale, Turkey
${ }^{2}$ University of Health Sciences Turkey, Ankara City Hospital, Clinic of Cardiovascular Surgery Ankara, Turkey

\begin{abstract}
Objectives: The present study aimed to analyze the prognostic value of preoperative serum vitamin D level in patients who underwent coronary artery bypass graft (CABG) surgery.

Materials and Methods: The data of 360 adult patients who underwent isolated $\mathrm{CABG}$ surgery were retrospectively reviewed. We reached the data of preoperative serum vitamin D [25-hydroxyvitamin D (25-OHD)] values of 305 patients. The patient population was divided into two groups based on preoperative serum 25-OHD levels with a normal range of $25-75 \mathrm{nmol} / \mathrm{L}$ (group I: patients with preoperative serum 25-OHD level $<25 \mathrm{nmol} / \mathrm{L}$ and group II: patients with preoperative serum 25-OHD level $\geq 25 \mathrm{nmol} / \mathrm{L}$ ). The effect of preoperative 25 -OHD level on operative mortality (mortality which occurred during the first 30 days after the operation) was determined using regression analysis and the results were expressed as Odds
\end{abstract}

ratio (OR) with a $95 \%$ confidence interval (CI). A p value $<0.05$ was considered statistically significant.

Results: In the present study, operative mortality was $3.93 \%(\mathrm{n}=12)$. One hundred and fifty seven patients $(51.5 \%)$ had serum 25-OHD levels $<25 \mathrm{nmol} / \mathrm{L}$. The mean serum 25-OHD levels were significantly lower in females than in males $(p<0.001)$. On logistic regression analysis, preoperative serum 25-OHD level was found to be independently associated with operative mortality (OR: 0.201, 95\% CI: 0.043- 0.935; $\mathrm{p}=0.041$ ).

Conclusion: The presence of vitamin D deficiency seems to be an independent predictor of operative mortality after cardiac surgery in this retrospective study; however, prospective randomized trials are warranted to clarify the effect of preoperative vitamin D supplementation on postoperative outcomes in cardiac surgical patients.

Keywords: Vitamin D, cardiac surgery, operative mortality

\footnotetext{
Address for Correspondence: Atike Tekeli Kunt, Kırıkkale University Faculty of Medicine, Department of Cardiovascular Surgery, Kirikkale, Turkey

e-mail: atikemd@gmail.com ORCID: orcid.org/0000-0001-9764-7393

Received: 20.08.2020 Accepted: 28.08.2020
}

Cite this article as: Tekeli Kunt A, Tümer NB, Özışık K, Günaydın S. Preoperative Vitamin D Level Predicts Operative Mortality After Cardiac Surgery. EJCM 2020;8(3):146-151.

DOI: 10.32596/ejcm.galenos.2020.08.043

${ }^{\circ}$ Copyright 2020 by Heart and Health Foundation of Turkey (TÜSAV) / E Journal of Cardiovascular Medicine published by Galenos Publishing House. 


\section{Introduction}

Robert Goetz was the first to perform coronary artery bypass grafting (CABG) surgery in 1960, and after that CABG became the most commonly performed cardiac surgery procedure worldwide ${ }^{(1,2)}$. Despite technological advances and advancements of surgical experience and perioperative care, the short term (in-hospital and/or 30 -day) mortality of CABG varies from $1 \%$ to $5 \%{ }^{(3)}$. To predict the operative mortality which occur during the first 30 days after CABG, several risk scoring systems and additional tools as biomarkers have been developed ${ }^{(4,5)}$. The most commonly used and well-known biomarkers are troponins, brain natriuretic peptide and $\mathrm{N}$-terminal fragment of brain natriuretic peptide ${ }^{(6,7)}$.

Vitamin D is a steroid hormone and has a role in bone metabolism. It is produced on the skin by the effect of sunlight. It is also important for immunity, cardiovascular, and central nervous systems ${ }^{(8)}$. It is known to play a role in the metabolism of insulin and the development of obesity ${ }^{(9)}$. Vitamin D deficiency is a global health problem and many adults and also infants have low vitamin D levels worldwide ${ }^{(10)}$. Vitamin D has protective effects on atherosclerosis by increasing nitric oxide levels and decreasing oxidative stress in endothelium and also by inhibiting the proliferation of smooth muscle cells in vessels; thus, vitamin D deficiency is suggested to be associated with increased risks of coronary artery disease $^{(11)}$. In the present study, we analyzed the association of preoperative vitamin D levels with operative mortality in patients who underwent CABG surgery.

\section{Materials and Methods}

\section{Patients}

We retrospectively reviewed the data of 360 adult patients who underwent isolated CABG surgery from January 2016 to January 2018. We reached the data of preoperative serum vitamin D [25-hydroxyvitamin D (25OHD)] values of 305 patients. All patients previously had granted permission for the use of their medical records for research purposes and institutional review board approved the study (no: E-19-048, date: 3.10.2019, Ankara City Hospital). For the present study, the patient population was divided into two groups based on preoperative serum 25-OHD levels with a normal range of $25-75 \mathrm{nmol} / \mathrm{L}$ (group I: patients with preoperative serum 25-OHD level $<25 \mathrm{nmol} / \mathrm{L}$ and group II: patients with preoperative serum 25 -OHD level $\geq 25 \mathrm{nmol} / \mathrm{L}$ ). The primary outcome was the operative mortality. Operative mortality was defined as mortality which occurred during the first 30 days after the operation. Patients with recent myocardial infarction, emergent surgery, and patients undergoing operations other than $\mathrm{CABG}$ or in conjunction with $\mathrm{CABG}$ were excluded from the study.

All operations were performed in a standardized approach and by the same surgical team. Terumo roller pump (Terumo Advanced Perfusion System 1, USA) and membrane oxygenators (Inspire 8, LivaNova Sorin Group, Italy) were used with mild to moderate (28$32{ }^{\circ} \mathrm{C}$ ) hypothermia and pulsatile flow of $2.2-2.4 \mathrm{~L} / \mathrm{m}^{2}$. Myocardial protection was achieved with tepid antegrade blood cardioplegia. Patients were followed in the intensive care unit (ICU), in accordance with the protocols of our institution.

\section{Statistical Analysis}

All statistics were performed using SPSS version 18.0 for Windows (IBM Corporation, New York, USA). Continuous variables were expressed as mean \pm standard deviation and were compared by unpaired Student's t-test or chi-square test. The effect of preoperative serum 25-OHD level on operative mortality after CABG was determined using logistic regression analysis, and the results were expressed as Odds ratio (OR) with a 95\% confidence interval (CI). A p value $<0.05$ was considered statistically significant.

\section{Results}

In this study, $51.5 \%$ of patients had preoperative serum 25-OHD levels $<25 \mathrm{nmol} / \mathrm{L}$. Preoperative patient characteristics and intraoperative data did not show statistical significance between the two groups other 
than gender, vitamin D levels, and Euroscore II (Table 1). The preoperative mean serum 25 -OHD was $19.1 \pm 4.4$ $\mathrm{nmol} / \mathrm{L}$ in group I and $48.2 \pm 16.4 \mathrm{nmol} / \mathrm{L}$ in group II $(\mathrm{p}<0.001)$. Preoperative mean serum 25-OHD levels were significantly lower in females than in males $(31.0 \pm 18.4$ $\mathrm{nmol} / \mathrm{L}, 35.6 \pm 18.8 \mathrm{nmol} / \mathrm{L}$, respectively $\mathrm{p}=0.035)$. On logistic regression analysis, the presence of lower serum 25-OHD levels was shown to be associated with an increased incidence of operative mortality (OR: 0.201, 95\% CI: 0.043-0.935; $\mathrm{p}=0.041)$. Logistic regression analysis also revealed that Euroscore II was the other independent risk factor for operative mortality after isolated $\mathrm{CABG}$ in this study (OR: $1.270,95 \% \mathrm{CI}: 1.034-$ $1.559, \mathrm{p}=0.023$ ).

The postoperative data of the patients are shown in Table 2. Prolonged ventilatory support was necessary in $3.8 \%$ of patients. Postoperative acute kidney injury was observed in $17 \%$ of patients. Kidney injury was interpreted according to RIFLE classification ${ }^{(12)}$; RIFLE (R: risk, I: injury, F: failure, L: loss, and E: end-stage kidney disease). When results were compared according to the RIFLE classification, 36 patients were in group I

Table 1. Baseline and perioperative characteristics of patients

\begin{tabular}{|c|c|c|c|}
\hline Clinical characteristics & $\begin{array}{l}\text { Group I* } \\
(n=157)\end{array}$ & $\begin{array}{l}\text { Group II** } \\
(n=148)\end{array}$ & $\mathbf{p}$ \\
\hline Age, years & $69.8 \pm 7.1$ & $68.2 \pm 8.0$ & 0.359 \\
\hline Female $(n)$ & 95 & 62 & $0.001^{\neq}$ \\
\hline Body mass index, $\mathrm{kg} / \mathrm{m}^{2}$ & $27.2 \pm 4.7$ & $28.1 \pm 4.9$ & 0.237 \\
\hline Hypertension (n) & 91 & 87 & 0.488 \\
\hline Diabetes mellitus ( $n$ ) & 64 & 74 & 0.066 \\
\hline Hyperlipidemia (n) & 90 & 78 & 0.243 \\
\hline Serum 25-OHD (nmol/L) & $19.1 \pm 4.4$ & $48.2 \pm 16.4$ & $<0.001^{\neq}$ \\
\hline CPB time (min) & $109.6 \pm 41.3$ & $102.7 \pm 39.5$ & 0.063 \\
\hline Cross-clamp time (min) & $62.1 \pm 22.6$ & $58.6 \pm 24.7$ & 0.168 \\
\hline LV function (\%) & $52.4 \pm 10.7$ & $54.4 \pm 9.4$ & 0.052 \\
\hline Serum creatinine (mg/dL) & $0.95 \pm 0.2$ & $0.92 \pm 0.2$ & 0.219 \\
\hline $\begin{array}{l}\text { Creatinine clearance } \\
(\mathrm{mL} / \mathrm{min})\end{array}$ & $84.1 \pm 35.9$ & $90.1 \pm 35.2$ & 0.156 \\
\hline Euroscore II (\%) & $3.9 \pm 2.6$ & $2.9 \pm 2.1$ & $0.009 \neq$ \\
\hline
\end{tabular}

and 16 patients were in group II $(\mathrm{p}=0.004)$. Operative mortality was $3.93 \%$. Nine patients died due to low cardiac output and multiorgan failure during the hospital stay, one patient died due to pulmonary embolism on the $15^{\text {th }}$ postoperative day, one patient due to mediastinitis on the $23^{\text {rd }}$ postoperative day, and one patient died due to cerebrovascular accident on the $18^{\text {th }}$ postoperative day.

\section{Discussion}

The aim of the present study was to determine whether preoperative serum 25-OHD levels were associated with operative mortality after CABG. Our retrospective study illustrated that lower preoperative serum level of 25OHD was associated with operative mortality. Our results showed that $51.5 \%$ of patients had preoperative serum 25-OHD levels $<25 \mathrm{nmol} / \mathrm{L}$. It is known that vitamin D deficiency rate is increasing worldwide and approximately $30 \%$ of people in all age groups have deficiency or insufficiency ${ }^{(13)}$. Vitamin D deficiency is common among older and critically ill patients. As we analyzed the cardiac surgical patients who were old and critically ill in nature, our results were similar with literature in this regard ${ }^{(14)}$

Vitamin D deficiency is reported to be associated with increased morbidity and even mortality in critically ill patients ${ }^{(15-17)}$. Although the exact mechanism to elucidate this association is not well understood, higher incidence of postoperative inflammatory processes in vitamin D deficiency may be one of the explanations ${ }^{(18)}$. Cardiac

Table 2. Postoperative data of the patients

\begin{tabular}{|l|l|l|l|}
\hline & $\begin{array}{l}\text { Group I* } \\
(\mathbf{n = 1 5 7 )}\end{array}$ & $\begin{array}{l}\text { Group II** } \\
(\mathbf{n = 1 4 8 )}\end{array}$ & $\mathbf{p}$ \\
\hline Mean ICU time (h) & $55.3 \pm 25.9$ & $49.3 \pm 22.2$ & $0.031^{\ddagger}$ \\
\hline $\begin{array}{l}\text { Mean ventilatory support time } \\
\text { (h) }\end{array}$ & $9.2 \pm 11.4$ & $7.2 \pm 2.2$ & $0.038^{\ddagger}$ \\
\hline IABP support (n) & 12 & 3 & $0.032^{\ddagger}$ \\
\hline In-hospital stay time (d) & $6.8 \pm 2.5$ & $6.2 \pm 1.6$ & $0.013^{\ddagger}$ \\
\hline Operative mortality (n) & 12 & 2 & $0.036^{\ddagger}$ \\
\hline
\end{tabular}

ICU: Intensive care unit, $h$ : hours, IABP: Intra-aortic balloon pump, $d$ : Days, n: Number

${ }^{*}$ Group I: patients with preoperative serum 25-OHD levels <25nmol/L, ${ }^{* *}$ Group II: patients with preoperative serum $25-\mathrm{OHD}$ levels $\geq 25 \mathrm{nmol} / \mathrm{L}$. ${ }^{\ddagger} p<0.05$, statistically significant 
surgical patients are at risk of surgery-related inflammation. Cardiopulmonary bypass (CPB) results in an acute systemic inflammatory response syndrome and this is suggested to result in increased morbidity, development of organ dysfunctions, and mortality ${ }^{(19)}$. The inflammatory cascade is activated during $\mathrm{CPB}$ and proinflammatory cytokines as interleukin-6 (IL-6) and IL-8 are released, which results in immune system dysfunction ${ }^{(20,21)}$. The anti-inflammatory effects of vitamin D are documented and preoperative lower levels of vitamin D are found to be associated with postoperative organ dysfunction and mortality ${ }^{(14,22)}$. Additionally, experimental studies have indicated that due to the attenuation of vascular inflammation in vitamin D deficiency, cardiovascular risk increases ${ }^{(23)}$. Low levels of vitamin $\mathrm{D}$, which result in decreased anti-inflammatory capacity after cardiac surgery, could contribute to poor outcomes and increased operative mortality in the present study.

Our results revealed an increased ICU stay time and hospital stay times in patients with vitamin D deficiency, which is compatible with the studies in the literature $^{(19,23)}$. It was reported by Abou Zahr et al. ${ }^{(24)}$ that vitamin D levels were decreased immediately after CPB and increased after 24 hours. The explanation of the reduction was attributed to acute fluid shifts during $\mathrm{CPB}$ and the rise was attributed to renal recovery with improved perfusion after CPB. Recently, there are studies dealing with the role of vitamin $\mathrm{D}$ in postoperative outcomes $^{(25)}$. It has been suggested that preoperative vitamin $\mathrm{D}$ deficiency is associated with acute kidney injury, acute respiratory distress syndrome, neurologic dysfunctions, nosocomial infections, liver dysfunction, and cardiogenic shock after cardiac surgery ${ }^{(22)}$. Acute kidney injury was reported to be higher in group I in our study. Vitamin D supplementation is another issue that needs to be clarified as there is no consensus regarding whether it is necessary to supply vitamin D preoperatively or not, when to supply or in which dose it should be supplied. It is suggested that vitamin D supplementation may play a protective role against paroxysmal atrial fibrillation after cardiac surgery ${ }^{(26)}$. It is also reported that the optimization of vitamin D status in both critically ill adults and congenital heart disease patients could attenuate inflammation and nosocomial infection and improve cardiac function ${ }^{(27)}$.

Another finding in our study was the gender difference between the two groups. Vitamin D deficiency was more common among females in the present study. Quraishi et al. ${ }^{(28)}$ also reported vitamin D deficiency in females in their study; however, Ford et al. ${ }^{(29)}$ reported a higher prevalence of vitamin D deficiency among men and stated that the amount of body fat and/or its distribution could explain this gender difference.

The other independent risk factor for operative mortality in our study was found to be increased Euroscore II. Additive Euroscore II has been used worldwide in the clinical practice since 1999 and Euroscore II since 2012 for mortality prediction after cardiac surgery. Euroscore II, which is also used in our study, is suggested to be a good predictor of mortality in low risk cardiac surgical patients: however, it may underestimate mortality especially in high risk population ${ }^{(30)}$.

\section{Study Limitations}

There are some limitations of the present study. First, the study design was retrospective. Second, in the study, the sample size was relatively small and was limited to CABG patients and finally, we did not perform a propensity score matching to analyze the effect of Euroscore II or vitamin D deficiency on mortality.

\section{Conclusion}

In summary, the incidence of Vitamin D deficiency was $51.5 \%$ and the operative mortality was $3.93 \%$ in the present study. Vitamin D deficiency resulted in poor postoperative outcomes and increased operative mortality after $\mathrm{CABG}$. Prospective randomized studies that are designed to analyze the effect of vitamin D deficiency and its supplementation before surgery on postoperative outcomes are warranted. 


\section{Ethics}

Ethics Committee Approval: Institutional Review Board of Ankara City Hospital approved the study (no: E-19-048, date: 3.10.2019).

Informed Consent: All patients previously had granted permission for the use of their medical records for research purposes.

\section{Peer-review: Externally peer-reviewed.}

\section{Authorship Contributions}

Surgical and Medical Practices: A.T.K., N.B.T., K.Ö., S.G., Concept: A.T.K., N.B.T., K.Ö., S.G., Design: A.T.K., N.B.T., K.Ö., S.G., Data Collection or Processing: A.T.K., N.B.T., K.Ö., S.G., Analysis or Interpretation: A.T.K., N.B.T., K.Ö., S.G., Literature Search: A.T.K., N.B.T., K.Ö., S.G., Writing: A.T.K., N.B.T., K.Ö., S.G.

Conflict of Interest: No conflict of interest was declared by the authors.

Financial Disclosure: The authors declared that this study received no financial support.

\section{References}

1. Goetz RH, Rohman M, Haller JD, Dee R, Rosenak SS. Internal mammarycoronary artery anastomosis. A nonsuture method employing tantalum rings. J Thorac Cardiovasc Surg 1961;41:378-86.

2. Weiss AJ, Elixhauser A. Trends in Operating Room Procedures in U.S. Hospitals, 2001-2011: Statistical Brief \#171. In: Rockville MD (eds). Healthcare Cost and Utilization Project (HCUP) Statistical Briefs. Agency for Healthcare Research and Quality (US), 2006.

3. Ferguson TB Jr. Mortality in coronary artery bypass grafting: what's next? Circulation 2012;125:2409-11.

4. Geissler HJ, Hölzl P, Marohl S, et al. Risk stratification in heart surgery: comparison of six score systems. Eur J Cardiothorac Surg 2000;17:400-6.

5. Thomas MR, Lip GY. Novel Risk Markers and Risk Assessments for Cardiovascular Disease. Circ Res 2017;120:133-49.

6. Beattie WS, Wijeysundera DN. Perioperative cardiac biomarkers: the utility andtiming. Curr Opin Crit Care 2013;19:334-41.

7. Patel DM, Thiessen-Philbrook H, Brown JR, et al. Association of plasmasoluble ST2 and galectin-3 with cardiovascular events and mortality following cardiac surgery. Am Heart J 2020;220:253-63.

8. Roth DE, Abrams SA, Aloia J, et al. Global prevalence and disease burden of vitamin D deficiency: a roadmap for action in low- and middle-income countries. Ann N Y Acad Sci 2018;1430:44-79.
9. Talaei A, Mohamadi M, Adgi Z. The effect of vitamin D on insulin resistance in patients with type 2 diabetes. Diabetol Metab Syndr 2013;5:8.

10. Hilger J, Friedel A, Herr R, et al. A systematic review of vitamin D status in populations worldwide. Br J Nutr 2014;111:23-45.

11. Menezes AR, Lamb MC, Lavie CJ, DiNicolantonio JJ. Vitamin D and atherosclerosis. Curr Opin Cardiol 2014;29:571-7.

12. Bellomo R, Ronco C, Kellum JA, Mehta RL, Palevsky P. Acute Dialysis Quality Initiative workgroup. Acute renal failure - definition, outcome measures, animal models, fluid therapy and information technology needs: the Second International Consensus Conference of the Acute Dialysis Quality Initiative (ADQI) Group. Crit Care 2004;8:R204-12.

13. Holick MF. Vitamin D deficiency. N Engl J Med 2007;357:266-81.

14. Borgermann J, Lazouski K, Kuhn J, et al. 1,25-Dihydroxyvitamin D fluctuations in cardiac surgery are related to age and clinical outcome. Crit Care Med 2012;40:2073-81

15. Venkatram S, Chilimuri S, Adrish M, Salako A, Patel M, Diaz-Fuentes G. Vitamin D deficiency is associated with mortality in the medical intensive care unit. Crit Care 2011;15:R292.

16. Lee P, Nair P, Eisman JA, Center JR. Vitamin D deficiency in the intensive care unit: an invisible accomplice to morbidity and mortality? Intensive Care Med 2009;35:2028-32.

17. Matthews LR, Ahmed Y, Wilson KL, Griggs DD, Danner OK. Worsening severity of vitamin D deficiency is associated with increased length of stay, surgical intensive care unit cost, and mortality rate in surgical intensive care unit patients. Am J Surg 2012;204:37-43.

18. Zittermann A, Kuhn J, Ernst JB, et al. Circulating 25- Hydroxyvitamin $\mathrm{D}$ and 1,25-Dihydroxyvitamin D Concentrations and Postoperative Infections in Cardiac Surgical Patients: the CALCITOP-Study. PLoS One 2016;11:e0158532.

19. Paparella D, Yau TM, Young E. Cardiopulmonary bypass induced inflammation: Pathophysiology and treatment. An update. Eur J Cardiothorac Surg 2002;21:232-44.

20. Markewitz A, Lante W, Franke A, Marohl K, Kuhlmann WD, Weinhold C. Alterations of cell-mediated immunity following cardiac operations: Clinical implications and open questions. Shock 2001;16 (Suppl 1):10-5.

21. Schuett H, Luchtefeld M, Grothusen C, Grote K, Schieffer B. How much is too much? Interleukin-6 and its signalling in atherosclerosis. Thromb Haemost 2009;102:215-22.

22. Ney J, Heyland DK, Amrein K, et al. The relevance of 25-hydroxyvitamin $\mathrm{D}$ and 1,25-dihydroxyvitamin $\mathrm{D}$ concentration for postoperative infections and postoperative organ dysfunctions in cardiac surgery patients: The eVIDenCe study. Clin Nutr 2019;38:2756-62

23. Lavie CJ, Lee JH, Milani RV. Vitamin D and cardiovascular disease will it live up to its hype? J Am Coll Cardiol 2011;58:1547-56.

24. Abou Zahr R, Faustino EVS, Carpenter T, et al. Vitamin D Status After Cardiopulmonary Bypass in Children With Congenital Heart Disease. J Intensive Care Med 2017;32:508-13.

25. Krishnan A, Ochola J, Mundy J, et al. Acute fluid shifts influence the assessment of serum vitamin D status in critically ill patients. Crit Care 2010;14:216. 
26. Cerit L, Özcem B, Cerit Z, Duygu H. Preventive Effect of Preoperative Vitamin D Supplementation on Postoperative Atrial Fibrillation. Braz J Cardiovasc Surg 2018;33:347-52.

27. McNally JD, O'Hearn K, Lawson ML, et al. Prevention of vitamin D deficiency in children following cardiac surgery: study protocol for a randomized controlled trial. Trials 2015;16:402.

28. Quraishi SA, Litonjua AA, Elias KM, et al. Association between prehospital vitamin D status and hospital-acquired new-onset delirium. Br J Nutr 2015;113:1753-60.
29. Ford J, Hategan A, Bourgeois JA, Tisi DK, Xiong GL. Hypovitaminosis D in delirium: a retrospective cross-sectional study. Can Geriatr J 2013;16:18691.

30. Guillet L, Moury PH, Bedague D, et al. Comparison of the additive, logistic european system for cardiac operative risk (EuroSCORE) with the EuroSCORE 2 to predict mortality in high-risk cardiac surgery. Ann Card Anaesth 2020;23:277-82. 